ISSN = 1980-993X - doi:10.4136/1980-993X
www.agro.unitau.br/ambi-agua
E-mail: ambi-agua@agro.unitau.br
Tel.: (12) 3625-4116

\title{
Rainfall-runoff process analysis of the Pequeno River catchment, Curitiba metropolitan region, Brazil, with two hydrological models
} (doi:10.4136/ambi-agua.60)

\author{
Pedro Luiz Borges Chaffe ${ }^{1}$; Roberto Valmir da Silva ${ }^{1}$; Masato Kobiyama ${ }^{2}$ \\ ${ }^{1}$ Graduate course of Environmental Engineering, Federal University of Santa Catarina \\ ${ }^{2}$ Department of Sanitary and Environmental Engineering, Federal University of Santa Catarina, Caixa Postal \\ 476, Florianópolis-SC, CEP88040-900, Brasil. www.labhidro.ufsc.br \\ E-mail: \{chaffe, roberto, kobiyama\}@ens.ufsc.br
}

\begin{abstract}
The rainfall-runoff process of the Pequeno River catchment, located in the Curitiba metropolitan region, Paraná State, Brazil was analyzed with two hydrological models, TOPMODEL and HYCYMODEL. Both models were applied to a series of 3360 hourlyobserved rainfall-runoff data. The simulations of those models were compared in terms of total runoff generation and hydrograph separation. The uncertainty intervals were estimated for each model using the GLUE method. Both models presented a satisfactory and similar efficiency for the total runoff simulation. The ratio between total runoff and total precipitation was $0.79,0.81$ and 0.74 for the observed data, those calculated with TOPMODEL and with HYCYMODEL, respectively. The models also estimated a large quantity of the baseflow contributing to the total runoff $(77.7 \%$ with TOPMODEL and $84.5 \%$ with HYCYMODEL), but there was a significant difference of those quantities between the models. The surface flow analysis showed that TOPMODEL considered that the catchment saturates and drains faster than HYCYMODEL.
\end{abstract}

Keywords: Pequeno River catchment; rainfall-runoff process; TOPMODEL; HYCYMODEL.

\section{Análise do processo chuva-vazão da bacia do rio Pequeno, região metropolitana de Curitiba, Brasil, usando dois modelos hidrológicos}

\section{RESUMO}

O processo de chuva-vazão da bacia do rio Pequeno, localizada na região metropolitana de Curitiba, estado do Paraná, Brasil, foi analisado por meio de dois modelos hidrológicos, TOPMODEL e HYCYMODEL. Uma série de 3360 dados horários de chuva-vazão foi utilizada em ambos os modelos. As simulações foram comparadas em termos de vazão total e de separação de escoamento. Os intervalos de incerteza das simulações de cada modelo foram estimados pelo método GLUE. Ambos os modelos apresentaram eficiências satisfatórias e similares na simulação de escoamento total. A razão entre escoamento total e precipitação foi de $0,79,0,81$ e 0,74 para os dados observados, calculados com o TOPMODEL e com o HYCYMODEL, respectivamente. Os modelos estimaram uma grande quantidade de escoamento de base contribuindo para o escoamento total $(77,7 \%$ para o TOPMODEL e $84,5 \%$ para o HYCYMODEL), porém, houve uma diferença significativa dessas quantidades entre os modelos. A análise do escoamento superficial mostrou que o TOPMODEL considerou que a bacia satura e drena mais rapidamente do que nas simulações com o HYCYMODEL.

Palavras-chave: Bacia do rio Pequeno; processo chuva-vazão; TOPMODEL; HYCYMODEL. 


\section{INTRODUCTION}

The Pequeno River catchment, located in the Curitiba metropolitan region, Paraná State, Brazil, has undergone a fast and accelerated urbanization due to the economic development of this region. Hence, studies about hydrological processes in this catchment are very important to environmental planning (Santos, 2001; Santos and Kobiyama, 2008). For future problems solutions of urban drainage and drinking-water supply, the estimation of surface flow and baseflow, i.e., hydrograph separation, is an important item of this catchment hydrology. There are many different ways to analyze the hydrograph of a catchment. One of them is using hydrological models to simulate rainfall-runoff processes.

A well known rainfall-runoff models is TOPMODEL (Topography-based hydrological Model) (Beven and Kirkby, 1979). Because of its free availability in the Internet and its simple formulation, TOPMODEL has been widely used since it was first coded. This model is based on the concept of 'storage deficit', which is a function of a hydrological similarity index. This index is called 'topographic index' and is calculated from the catchment topography. TOPMODEL is considered a semi-distributed and physically based model, since runoff routing depends on the distribution of the topographic index in the catchment. It was previously applied to the Pequeno River catchment, but focusing on the saturated areas (Santos and Kobiyama, 2008) and on the comparison of different versions of the model (Silva and Kobiyama, 2007).

On the other hand, the HYCYMODEL (Hydrological Cycle Model) developed by Fukushima and Suzuki (1986) and Fukushima (1988) was based on hydrological processes observations in a small forested mountain catchment in Japan and is considered a conceptual and lumped model. This model estimates phenomenon such as evaporation, transpiration and hydrograph separation. HYCYMODEL was applied to some Brazilian catchments and showed satisfactory results (Kobiyama and Chaffe, 2008; Kobiyama et al., 2009).

The main objective of the present study was to analyze the rainfall-runoff processes of the Pequeno River catchment by applying and comparing results of these two different hydrological models, TOPMODEL and HYCYMODEL.

\section{MATERIAL AND METHODS}

\subsection{Study Area}

The Pequeno River catchment $\left(104 \mathrm{~km}^{2}\right)$ is located in São José dos Pinhais city, Curitiba metropolitan region, Paraná State, Brazil (Figure 1). The topography is characterized by moderate slopes and its elevation varies from $895 \mathrm{~m}$ to $1270 \mathrm{~m}$. The land use of this catchment comprises urban area (4\%), agriculture and exposed areas $(3 \%)$, forest $(54 \%)$, grassland (35\%), wetland (3\%) and others (1\%). At least $15 \%$ of the catchment is permanently saturated (Santos and Kobiyama, 2008). The mean annual precipitation is approximately 1400mm (Santos, 2001).

\subsection{Hydrological Data}

The hydrological data used in this study are from the Fazendinha gauge station and the Chácara Guajubi meteorological station (Figure 1). The evapotranspiration data used in TOPMODEL were calculated with the modified Penman method (Doorenbos and Pruit, 1977). The series of the observed rainfall and runoff data and the estimated evapotranspiration data are from August 14th, 2000, to January 1st, 2001, with 3360 hourly measured data (Figure 2). 

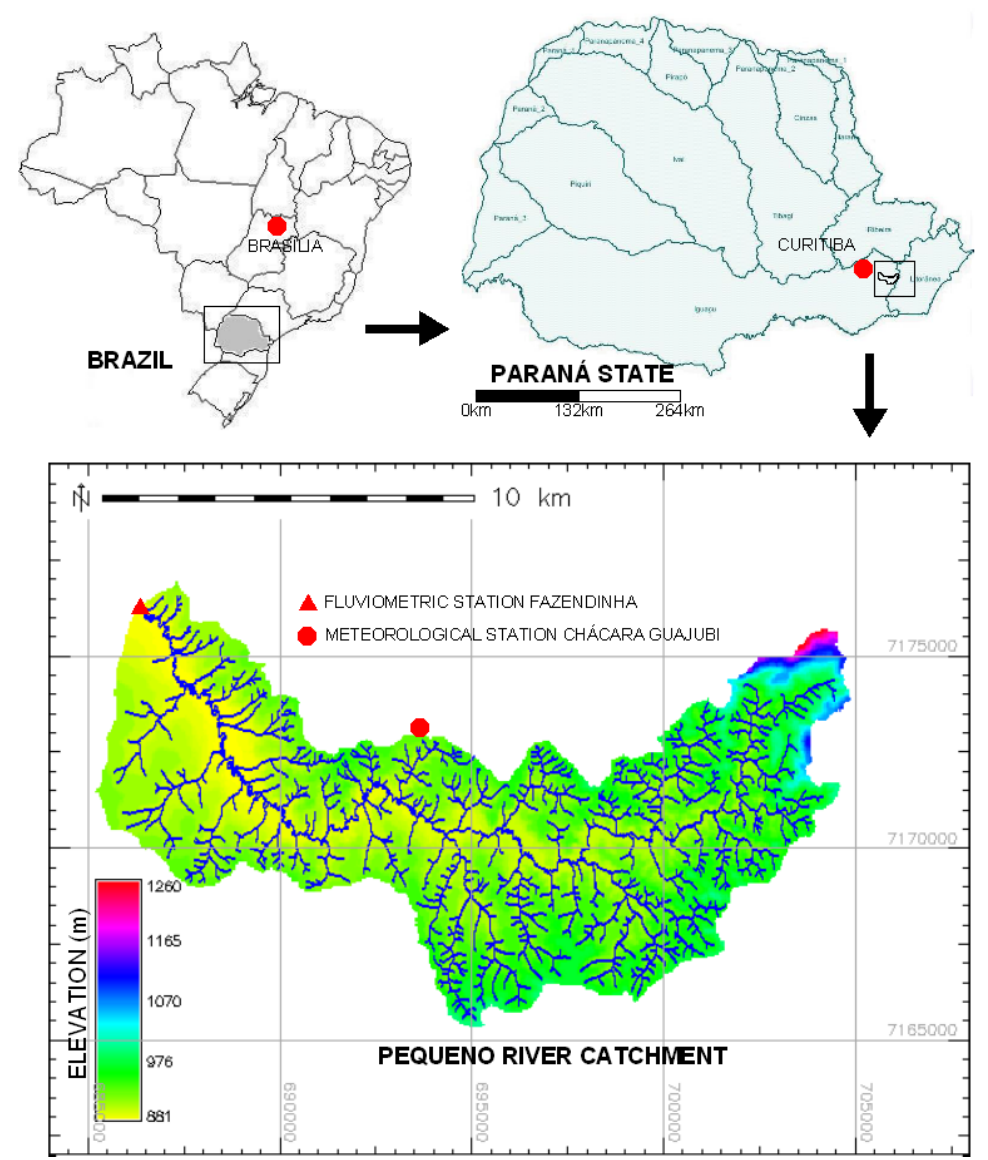

Figure 1. Pequeno River Catchment.

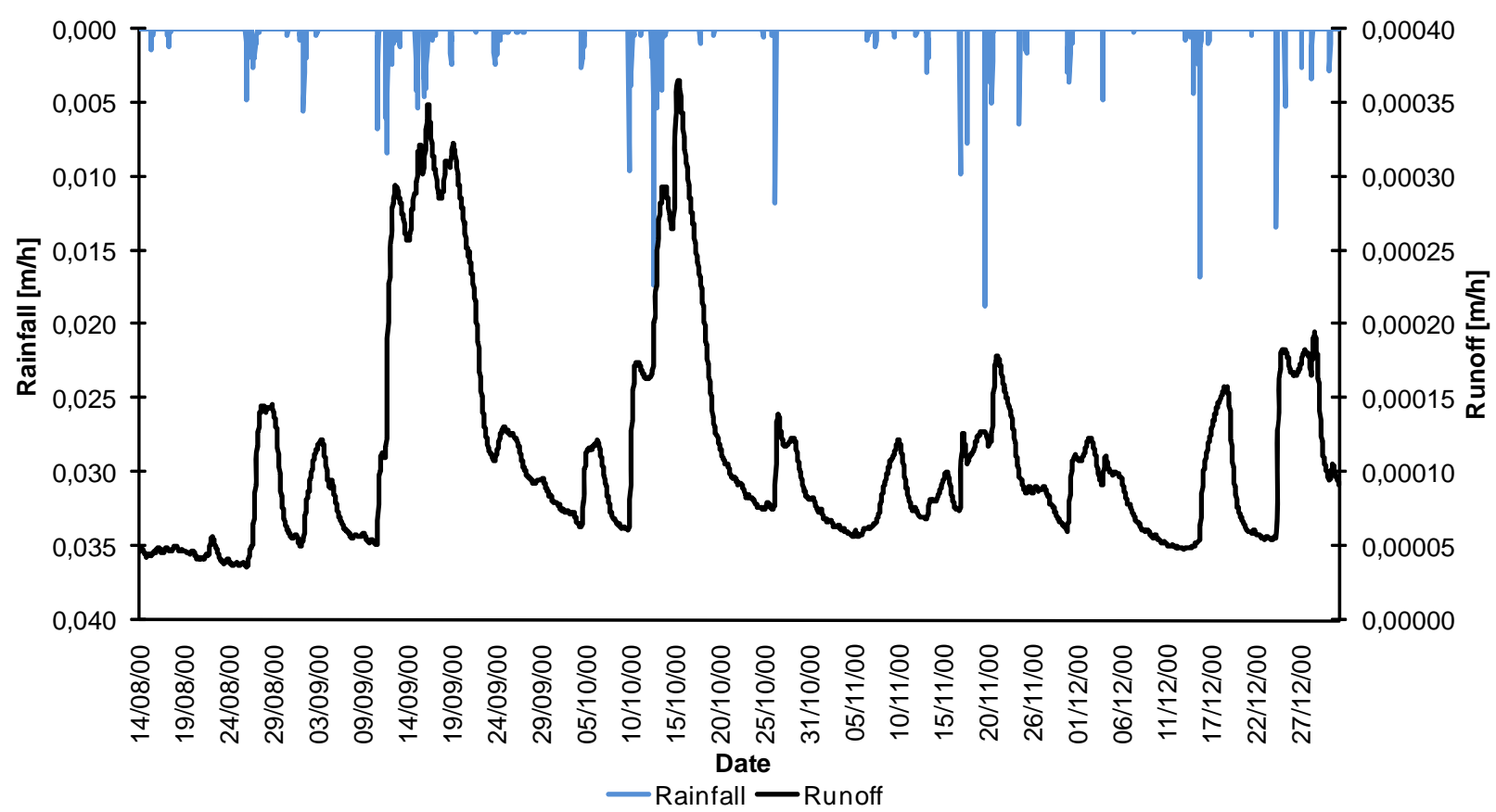

Figure 2. Rainfall-runoff data. 


\subsection{TOPMODEL}

The TOPMODEL is a rainfall-runoff model that uses the concept of hydrological similarity based on topography (Beven et al., 1995). This similarity is defined by the topographic index $\lambda_{i}$ :

$$
\lambda_{i}=\ln \left(\frac{a_{i}}{\tan \beta_{i}}\right)
$$

where $a_{\mathrm{i}}$ is the upslope contributing area per unit contour length for each cell $\mathrm{i}$ in the catchment; and $\tan \beta_{\mathrm{i}}$ is the slope of this cell measured with respect to plan distance.

The storage deficit $S_{i}$ for each cell with the same hydrological similarity is:

$$
S_{i}=S+m\left(\lambda-\lambda_{i}\right)
$$

where $S$ is the lumped or mean storage deficit for the entire catchment; $\lambda$ is the mean topographic index (approximated by a weighed average over the areas with the same hydrological similarity); $\lambda_{i}$ is the local topographic index and $m$ is a parameter associated with the rate of decline of the catchment recession curve.

For each time step the storage deficit is updated following the equation:

$$
S_{t}=S_{t-1}+\left(\frac{Q b_{t-1}-Q v_{t-1}}{A}\right)
$$

where $S_{t}$ is the updated value of the storage deficit; $S_{t-1}$ is the storage deficit in the previous time step; $Q b_{t-1}$ is the base flow in the previous time step; $Q v_{t-1}$ is the unsaturated zone recharge in the previous time step; and $A$ is the catchment area. This recharge is defined by:

$$
q_{v i}=\frac{S_{U Z}}{S_{i} T_{D}}
$$

where $S_{U Z}$ is the unsaturated zone deficit; and $T_{D}$ is residence time in the unsaturated zone. The maximum value for $S_{U Z}$ is determined by the parameter $S R_{M A X}$.

The baseflow is defined by:

$$
Q_{b}=Q_{S} e^{\left(\frac{-S}{m}\right)}
$$

where $Q_{s}$ is the discharge when the catchment is saturated and is calculated by:

$$
Q_{S}=A T_{0} e^{-\lambda}
$$

where $T_{0}$ is the soil saturated transmissivity, which is constant for the entire catchment.

In the first time step the mean storage deficit is estimated by: 


$$
S_{t=0}=-m \cdot \ln \left(\frac{Q_{0}}{Q_{S}}\right)
$$

where $\mathrm{Q}_{0}$ is the initial discharge at time $\mathrm{t}=0$.

TOPMODEL uses the Dunne (Dunne and Black, 1970) overflow generation mechanism, i. e., when the storage deficit (Equation 2) equals to zero. Flow routing is done through a time-area histogram. This histogram is derived from a distance-area function using the following equation:

$$
t c=\sum_{i=1}^{N} \frac{l_{i}}{R \tan \beta_{i}}
$$

where $t c$ is the time of concentration of a determined area of the catchment; $R V$ is a velocity parameter; and $l_{i}$ is the plan flow path length from a cell $i$ to the basin outlet.

\subsection{HYCYMODEL}

The HYCYMODEL consists of five tanks that express river and hillslope systems. For complete flowchart see Fukushima (1988), Kobiyama and Chaffe (2008). Using the ratio of impermeable area, $C$, rainfall is divided into the channel rainfall $R_{c}(t)$ and the gross rainfall $R_{g}(t)$ where $t$ is the time. Tank I shows the interception process, which is defined as:

$$
R_{n}(t)=A G \cdot R_{g}(t)-A I
$$

where $R_{n}(t)$ is the net rainfall; and $A G$ and $A I$ are the interception parameters. The interception $E_{i}(t)$ is the difference between $R_{n}(t)$ and $R_{g}(t)$.

The effective rainfall $R_{e}(t)$ can be determined with the storage $S_{u}(t-1)$ in Tank II and the net rainfall. $D_{16}$ and $D_{50}$ are defined as the effective top-soil depths, in which the ratios of the contributing area are equivalent to $16 \%$ and $50 \%$, respectively. Then, the standard deviation is:

$$
\sigma=\log \left(\frac{D_{50}}{D_{16}}\right)
$$

The variable $\xi$ is:

$$
\xi=\frac{\log \left(\frac{S_{u}(t-1)+R_{n}(t)}{D_{50}}\right)}{\sigma}
$$

The ratio of the contribution area, $m_{h y}$, is:

$$
m_{h y}=\int_{-\infty}^{\xi} \frac{1}{\sqrt{2 \pi}} \exp \left(-\frac{\xi^{2}}{2}\right) d \xi
$$

Finally,

$$
R_{e}(t)=m_{h y} \cdot R_{n}(t)
$$


Tanks III, IV and V represent the groundwater system, the subsurface water system and the channel system, which determine the base flow $Q_{b}(t)$, the subsurface flow on hillslope $Q_{h}(t)$ and the direct runoff in channel $Q_{c}(t)$, respectively. In Tanks II, III, IV and V, the relation between the storage $S_{h y}$ and the discharge $Q$ is expressed by the storage function, i.e.,

$$
S_{h y}=K Q^{P}
$$

where $K$ and $P$ are the storage function parameters. For Tanks II, III, IV and V, $K$ and $P$ are defined $K_{u}$ and $P_{u}, K_{b}$ and $P_{b}, K_{h}$ and $P_{h}$ and $K_{c}$ and $P_{c}$, respectively. Once Tanks IV and V form the direct runoff, the values of $P_{h}$ and $P_{c}$ are 0.6 derived from the kinematic wave aproach (Fukushima, 1988). And once Tank II, which presents the linear phenomenon, the value of $P_{u}$ is 1.0 . The value of $P_{b}$ is 0.1 and was calculated using the least square error (Fukushima, 1988).

The transpiration ratio is:

$$
E_{t}(t)=\operatorname{Delta}\left\{P_{t a}+P_{t b} \sin \left[30^{\circ}-(I-I G)\right]\right\}
$$

where Delta, $P_{t a}, P_{t b}$ and $I G$ are the parameters and $I$ is the month number (1 to 12). Transpiration in a drought situation decreases when the storage of Tank II is smaller than $S_{b c}$. The critical discharge for transpiration $Q_{b c}$ corresponds to $S_{b c}$. The evapotranspiration $E(t)$ is the sum of $E_{i}(t), E_{t}(t)$ and the channel evaporation $E_{c}(t)$.

For hourly measured data, five more parameters need to be calibrated in the interception subsystem than those in Kobiyama and Chaffe (2008): $a_{1}$ (rate of rain interception by canopy), $a_{2}$ (rate of stem flow), $S_{1}$ (maximum storage in canopy), $S_{2}$ (maximum storage in stems) and EVI (evaporation intensity of the intercepted rain). This is modified structure of Tank I as proposed by (Suzuki et al., 1979).

\subsection{The GLUE method}

In a model calibration, it is very likely that more than one set of parameters produce similar results. This particularity is called "equifinality" (Beven and Binley, 1992). Equifinality, data acquisition and model formulation are some of the many causes of uncertainty in a modeling study. Therefore, to estimate the uncertainty in a given simulation, Beven and Binley (1992) proposed the use of the GLUE (Generalized Likelihood Uncertainty Estimation) Method. In order to use this method, it is required to: (1) choose a feasible sampling range for each parameter; (2) choose a method for generating parameter values; (3) choose an appropriate likelihood measure; and (4) decide the likelihood value for acceptance or rejection of a determined parameter set.

The sampling range might be determined based on field observation, literature recommendations and previous simulations. For this study, it was chosen the Monte Carlo method for parameter sampling, which generates random values based on a uniform probability distribution. The likelihood measure should be determined by the prediction problem nature. In the present study, the Nash coefficient (Nash and Sutcliffe, 1970) was used because of its sensitivity to hydrograph peaks. 


$$
E(\Theta)=1-\frac{\sum_{t=1}^{N}(o(t)-\hat{o}(t \mid \Theta))^{2}}{\sum_{t=1}^{N}(o(t)-\bar{o})^{2}}
$$

where $E(\Theta)$ is the Nash coefficient for the set of parameters $\Theta$; $o(t)$ is the variable observed in the time step $t ; \hat{o}(t \mid \Theta)$ is the variable calculated for the time step t using the set of parameters $\Theta ; o$ is the mean value of the observed variable; and $N$ is the number of time steps.

\subsection{Parameter Estimation}

Five parameters in TOPMODEL and sixteen in HYCYMODEL needed to be calibrated. The sampling range for each parameter in both models was chosen based on previous simulations. The parameters and ranges used for calibrating the TOPMODEL and HYCYMODEL are in Table 1 and 2, respectively. Also based on previous simulations, the Nash coefficient (E) equal to 0.3 was adopted as the likelihood value for acceptance (behavioral) or rejection (non-behavioral) of the parameter set.

Table 1. TOPMODEL parameters and sampling range.

\begin{tabular}{cc}
\hline Parameter & Range \\
\hline$m(\mathrm{~m})$ & $0.003-0.100$ \\
$\ln T_{0}\left(\ln \left(\mathrm{m}^{2} \mathrm{~h}^{-1}\right)\right)$ & $0.001-10.000$ \\
$T_{D}\left(\mathrm{~h} \mathrm{~m}^{-1}\right)$ & $0.05-120.00$ \\
$R V\left(\mathrm{~m} \mathrm{~h}^{-1}\right)$ & $300-2000$ \\
$S R_{M A X}(\mathrm{~m})$ & $0.00001-0.00200$ \\
\hline
\end{tabular}

Table 2. HYCYMODEL parameters and sampling range.

\begin{tabular}{cccc}
\hline Parameter & Range & Parameter & Range \\
\hline$C$ & $0.010-0.100$ & $a_{2}$ & $0.100-0.900$ \\
$D_{16}(\mathrm{~mm})$ & $10.0-30.0$ & $S_{l}(\mathrm{~mm})$ & $1.000-1.800$ \\
$D_{50}(\mathrm{~mm})$ & $50.0-80.0$ & $S_{2}(\mathrm{~mm})$ & $0.100-0.900$ \\
$K_{c}\left(\mathrm{~mm}^{2 / 5} \mathrm{~h}^{3 / 5}\right)$ & $1.0-200.0$ & $E V I(\mathrm{~mm} / \mathrm{h})$ & $0.010-0.800$ \\
$K_{h}\left(\mathrm{~mm}^{2 / 5} \mathrm{~h}^{3 / 5}\right)$ & $1.0-200.0$ & $P_{t a}(\mathrm{~mm})$ & $10.00-50.00$ \\
$K_{u}(\mathrm{~h})$ & $5.0-300.0$ & $P_{t b}(\mathrm{~mm})$ & $10.00-50.00$ \\
$K_{b}\left(\mathrm{~mm}^{9 / 10} \mathrm{~h}^{1 / 10}\right)$ & $50.0-1000.0$ & $I G$ & $9.0-14.0$ \\
$a_{1}$ & $0.100-0.900$ & $Q_{b c}(\mathrm{~mm} /$ day $)$ & $0.6-2.0$ \\
\hline
\end{tabular}

\section{RESULTS AND DISCUSSION}

Both models were applied to the series of 3360 hourly observed data. Among the twenty thousand runs carried out for each model, there were 11045 and 4710 sets of parameters considered behavioral ( $\mathrm{E} \geq 0.3$ ) in TOPMODEL and in HYCYMODEL, respectively. Using the behavioral simulations, the uncertainty bounds of $5 \%$ and $95 \%$ were calculated for each model. Figure 3 shows the observed discharge and the uncertainty bounds for TOPMODEL and HYCYMODEL. 


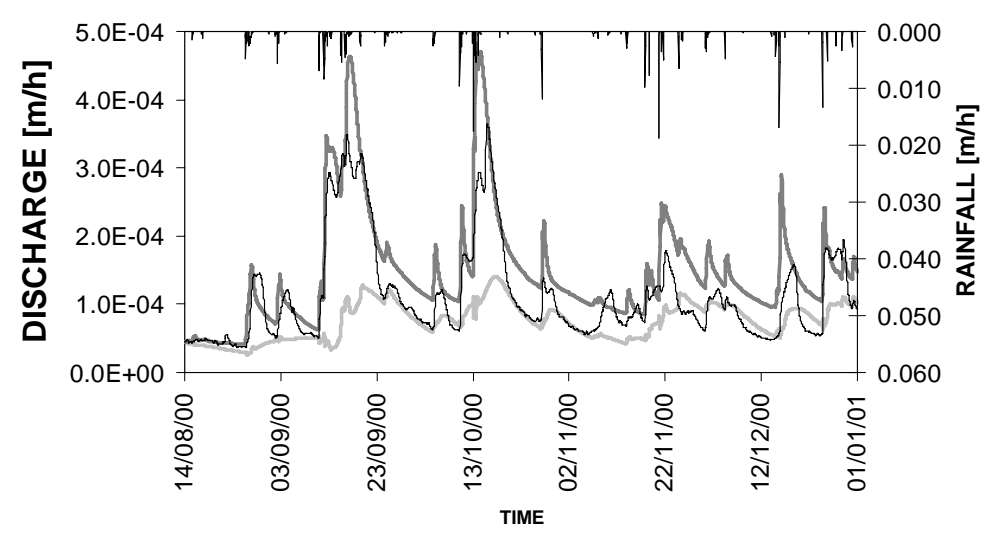

(a) - 5\% Bound - 95\% Bound - Observed Runoff - RAINFALL

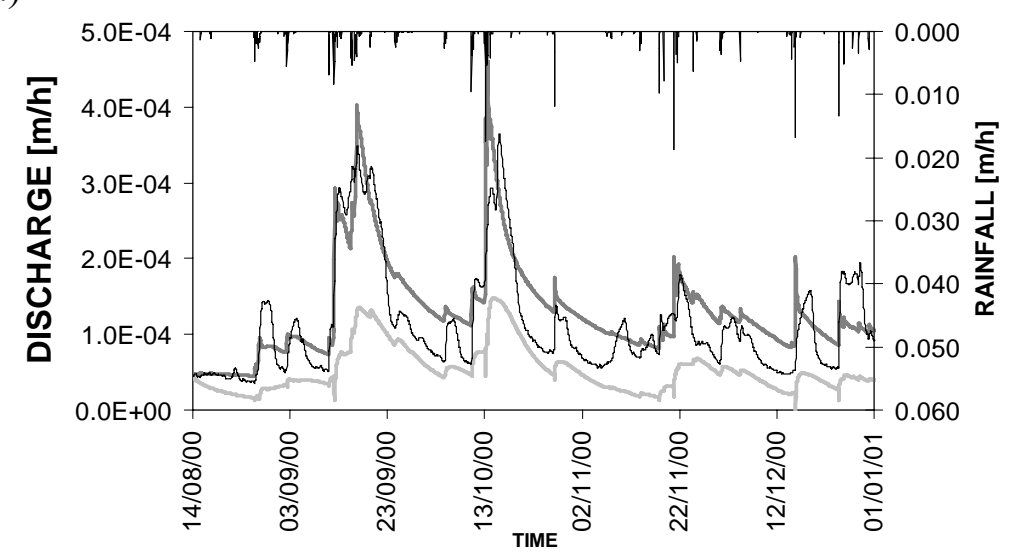

(b) $5 \%$ Bound - $95 \%$ Bound - Observed Runoff - RAINFALL

Figure 3. Uncertainty bounds: (a) TOPMODEL and (b) HYCYMODEL.

The sum of the distances between the upper bound and the lower one is smaller for TOPMODEL $\left(2.43 \times 10^{-1} \mathrm{~mm} / \mathrm{h}\right)$ than for HYCYMODEL $\left(2.62 \times 10^{-1} \mathrm{~mm} / \mathrm{h}\right)$. That is normal because the GLUE method tries to identify the uncertainty related to model calibration and TOPMODEL had fewer parameters to be calibrated than HYCYMODEL. However, the variance of the uncertainty interval of TOPMODEL is $1.05 \times 10^{-8}$ which is larger than that of HYCYMODEL, i.e., $7.80 \times 10^{-9}$. It occurs because, even though the uncertainty limits of TOPMODEL are narrower in the hydrograph recession, they are wider in the hydrograph peaks. This might be due to a higher sensitivity of TOPMODEL to the parameters related to runoff generation $\left(m, \ln T o\right.$ and $S R_{M A X}$ ). It seems that, for this series, HYCYMODEL is more sensitive to the parameter related to potential evapotranspiration $I G$, which has little influence on the discharge peaks.

The best set of the parameters, which resulted the highest $E$ values, for TOPMODEL and HYCYMODEL are in Table 3 and 4, respectively. The $E$ values for the best simulation of TOPMODEL and HYCYMODEL were 0.83 and 0.82 , respectively. These values show that both models possessed a similar efficiency for the Pequeno River catchment. The hydrographs produced with the best set of parameters with TOPMODEL and HYCYMODEL are in Figure 4 and 5. 
Table 3. TOPMODEL best set of parameters.

\begin{tabular}{cc}
\hline Parameter & Value \\
\hline$m(\mathrm{~m})$ & 0.0301 \\
$\ln T_{0}\left(\ln \left(\mathrm{m}^{2} \mathrm{~h}^{-1}\right)\right)$ & 0.11 \\
$T_{D}\left(\mathrm{~h} \mathrm{~m}^{-1}\right)$ & 86.3 \\
$R V\left(\mathrm{~m} \mathrm{~h}^{-1}\right)$ & 316 \\
$S R_{\text {MAX }}(\mathrm{m})$ & 0.00242 \\
\hline
\end{tabular}

Table 4. HYCYMODEL best set of parameters.

\begin{tabular}{cccc}
\hline Parameter & Value & Parameter & Value \\
\hline$C$ & 0.092 & $a_{2}$ & 0.377 \\
$D_{16}(\mathrm{~mm})$ & 28.5 & $S_{1}(\mathrm{~mm})$ & 1.265 \\
$D_{50}(\mathrm{~mm})$ & 79.8 & $S_{2}(\mathrm{~mm})$ & 0.845 \\
$K_{c}\left(\mathrm{~mm}^{2 / 5} \mathrm{~h}^{3 / 5}\right)$ & 51.2 & $E V I(\mathrm{~mm} / \mathrm{h})$ & 0.145 \\
$K_{h}\left(\mathrm{~mm}^{2 / 5} \mathrm{~h}^{3 / 5}\right)$ & 199.8 & $P_{t a}(\mathrm{~mm})$ & 24.66 \\
$K_{u}(\mathrm{~h})$ & 38.9 & $P_{t b}(\mathrm{~mm})$ & 38.24 \\
$K_{b}\left(\mathrm{~mm}^{9 / 10} \mathrm{~h}^{1 / 10}\right)$ & 266.7 & $I G$ & 13 \\
$a_{1}$ & 0.829 & $Q_{b c}(\mathrm{~mm} /$ day $)$ & 0.7 \\
\hline
\end{tabular}

The ratio between total runoff and total precipitation for this series was $0.79,0.81$ and 0.74 for the observed data, and the ones calculated with TOPMODEL and HYCYMODEL, respectively. Figure 4 shows the hydrograph separation with TOPMODEL. The contribution of baseflow to the total runoff is $77.7 \%$. In the hydrograph peaks, there is a large influence of surface flow and in the recession there is almost only baseflow. This occurs because the surface flow generation process is based on the soil saturation. According to Equation 4, the baseflow rises exponentially with the increase of the catchment saturation. The surface flow is calculated based on the rain that falls over the saturated area. Therefore, after the end of the precipitation event plus the contribution time of the entire saturated area, there is only a baseflow contributing for the total runoff plus the return flow from river channels.

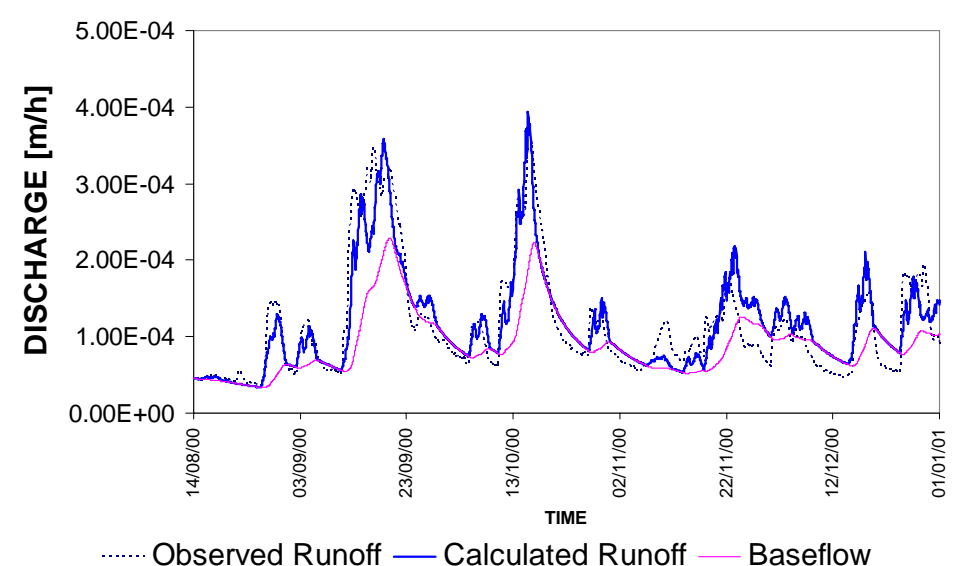

Figure 4. Hydrograph calculated with TOPMODEL. 
The hydrograph separation with HYCYMODEL is shown in Figure 5. The contribution of baseflow to the total runoff is $84.5 \%$. Different from the result with TOPMODEL, the simulation showed a larger contribution of baseflow in the hydrograph rising and the first declining part was composed by surface flow and baseflow. The surface flow generation process in HYCYMODEL is dependent not only on saturation but also on storage in two tanks. That is why there might be contribution of surface flow to the first declining part of the hydrograph.

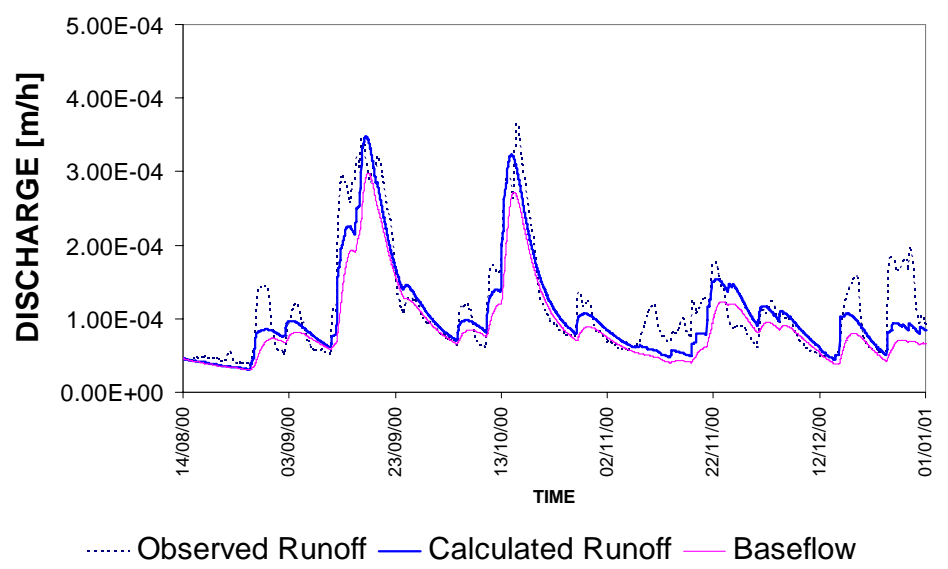

Figure 5. Hydrograph calculated with HYCYMODEL.

Both models simulated a large quantity of the baseflow to the total runoff and confirmed field observation results in different catchments such as reported by Sklash (1990). But there is a significant difference of these estimated quantities between the models. This difference is related to how they modeled the saturation process in the catchment. HYCYMODEL simulated a contribution of surface flow throughout all the declining parts of the hydrograph. The saturation and drainage processes (velocity and area) in catchment occur more quickly with TOPMODEL than HYCYMODEL (Figure 6).

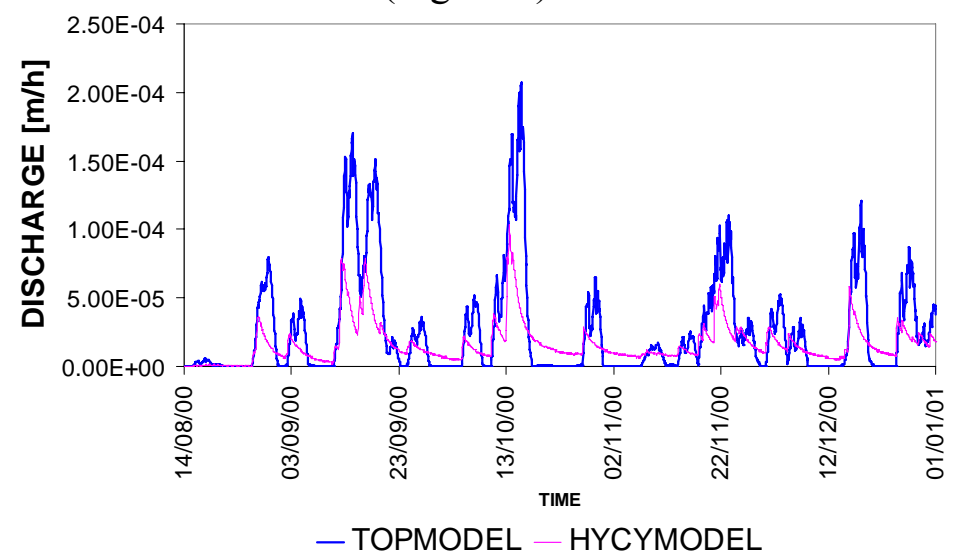

Figure 6. Surface Runoff calculated with TOPMODEL and HYCYMODEL.

\section{CONCLUSIONS}

This paper analyzed the rainfall-runoff process of the Pequeno River catchment with two different models, TOPMODEL and HYCYMODEL. The models were applied to a series of 3360 hourly observed data. The GLUE method was applied in order to determine uncertainty due to model calibration, and the uncertainty bounds of $5 \%$ and $95 \%$ were calculated for each model using the behavioral simulations $(E \geq 0.3)$. The uncertainty intervals are wider at the 
hydrograph peaks but narrower in the declining part with TOPMODEL than HYCYMODEL. It is probably due to a higher sensitivity of TOPMODEL to the parameters related to runoff generation.

For the hydrograph generation, TOPMODEL and HYCYMODEL presented a satisfactory and similar efficiency for the Pequeno River catchment with $E$ values equal to 0.83 and 0.82 respectively. Although the distributed model has some advantages such as saturated area mapping, the use of the lumped one is feasible to this catchment for hydrograph generation purposes

The total runoff ratio for the observed data, calculated with TOPMODEL and HYCYMODEL are $0.79,0.81$ and 0.74 , respectively. Compared to the observed data, HYCYMODEL seems to be overestimating water losses within this catchment.

In terms of hydrograph separation, both models simulated a large contribution of baseflow to the total runoff. However, there is a significant difference of these quantities between the models. TOPMODEL considered the catchment to saturate and drain faster than HYCYMODEL. It is hard to determine which model more accurately represents a real process of hydrograph separation in this catchment using only rainfall-runoff data. Hence, the use of tracer hydrograph separation should be realized to validate and improve the models.

\section{ACKNOWLEDGEMENTS}

The authors thank the CNPq for scholarship and Mr. Irani dos Santos (Federal University of Paraná) for hydrological database support.

\section{REFERENCES}

BEVEN, K. J.; BINLEY, A. The future of distributed models: model calibration and uncertainty prediction. Hydrological Processes, Chichester, v. 26, p. 279-298, 1992.

BEVEN, K. J.; KIRKBY, M. J. A physically based, variable contributing area model of basin hydrology. Hydrological Sciences Bulletin, Wallingford, v. 24, p. 43-69, 1979.

BEVEN, K. J.; LAMB, R.; QUINN, P.; ROMANOWICZ, R.; FREER, J. Topmodel. In: Computer Models of Watershed. Highlands Ranch: Water Resources Publication, 1995.p. $627-668$.

DOORENBOS, J.; PRUIT, W. O. Crop water requirements. Rome: FAO, 1977. p. 144.

DUNNE, T.; BLACK, R. D. Partial-area contributions to storm runoff in a small New England watershed. Water Resources Research, Washington, v.6, p. 1296-1311, 1970.

FUKUSHIMA, Y. A model of river flow forecasting for small forested mountain catchment. Hydrological Processes, Chichester, v. 2, p. 167-185, 1988.

FUKUSHIMA, Y.; SUZUKI, M. Hydrological cycle model for mountain watersheds and its applicatioin to the continuous 10 years recrds at intervals of both a day and an hour of Kiryu Watershed, Shiga Prefecture. Buletim University Forest-Kyoto Univ., v. 57, p. 162-185, 1986.

KOBIYAMA, M.; CHAFFE, P. L. B. Water balance in Cubatão-Sul river catchment, Santa Catarina, Brazil. Ambi-Água, Taubaté, v. 3, n. 1, p. 5-17, 2008. 
KOBIYAMA, M.; CHAFFE, P. L. B.; ROCHA, H. L.; CORSEUIL, C. W.; MALUTTA, S.; GIGLIO, J. N.; MOTA, A. A.; SANTOS, I.; RIBAS JUNIOR, U.; LANGA, R. Implementation of school catchments network for water resources management of the Upper Negro River region, southern Brazil. In: MAKOTO TANIGUCHI; WILIAM C. BURNETT; YOSHINORI FUKUSHIMA; MARTIN HAIGH; YU UMEZAWA. (ORG.). From Headwater to the Ocean: Hydrological changes and watershed management. London: Taylor \& Francis, 2009. In press. p. 151-157.

NASH, J. E.; SUTCLIFFE, J. V. River flow forecasting through conceptual models I: A discussion of principles. Journal of Hydrology, Amsterdam, v. 10, p. 282-290, 1970.

SANTOS, I. Modelagem geobiohidrológica como ferramenta no planejamento ambiental: estudo da bacia hidrográfica do Rio Pequeno, São José dos Pinhais - PR. 2001. 92f. Master's thesis (Soil Sciences) - Universidade Federal do Paraná, Curitiba, 2001.

SANTOS, I.; KOBIYAMA, M. Aplicação do TOPMODEL para determinação de áreas saturadas da bacia do Rio Pequeno, São José dos Pinhais, PR, Brasil. Ambi-Água, Taubaté, v. 3, n. 2, p. 77-79, 2008.

SILVA, R. V.; KOBIYAMA, M. Estudo comparativo de três formulações do TOPMODEL na bacia do Rio Pequeno, São José dos Pinhais, PR. Revista Brasileira de Recursos Hídricos, Porto Alegre, v. 12, p. 93-105, 2007.

SKLASH, M. G. Environmental isotope studies of storm and snowmelt generation. In: Process studies in Hillslope Hydrology. Chichester: John Wiley, 1990. p. 401-435.

SUZUKI, M.; KATO, H.; TANI, M.; FUKUSHIMA, Y. Throughfall, stemflow and rainfall interception in Kiryu experimental catchment (1) Throughfall and stemflow. J. Jap. For. Soc., Tokyo, v. 61, p. 202-210, 1979. 